\title{
Evaluation of Sugarcane Varieties against Pokkah boeng Disease and its Natural Occurrence
}

\author{
Abhay Ranjan ${ }^{1 *}$, Md. Minnatullah', Hari Chand ${ }^{2}$, Shiv Pujan Singh ${ }^{3}$ \\ and Saurabh Dubey ${ }^{1}$ \\ ${ }^{1}$ Department of Plant Pathology, ${ }^{2}$ Department of Entomology, ${ }^{3}$ Department of Economics, \\ Sugarcane Research Institute, Dr. Rajendra Prasad Central Agricultural University, Pusa, \\ Samastipur, Bihar-848125, India \\ *Corresponding author
}

\section{A B S T R A C T}

\section{Keywords \\ Sugarcane, Varieties, Evaluation, Pokkah boeng, Disease \\ Article Info \\ Accepted: \\ 04 September 2018 \\ Available Online: \\ 10 October 2018}

\begin{abstract}
An extensive survey was conducted in sugarcane reserved area under north Bihar during cropping season of 2017-18 to study the incidence and severity of disease. During survey, Pokkah boeng disease was observed which was ranged in between 1.1 and 21.2 per cent under different localities in sugarcane crop. In initial stage, the disease showed whitish, curling, twisting symptoms and bending of leaves from the top portion. During course of evaluation, two varieties namely CoSe 95422 and $\mathrm{CoSe} 92423$ were found highly susceptible, five varieties (CoS 8436, Bo 156, Co 1148, Co 0238 and Co 01148) were moderate and remaining varieties were recorded with mild incidence of Pokkah boeng disease out of twenty two varieties of sugarcane.
\end{abstract}

\section{Introduction}

Sugarcane is the most important cash cum industrial and emerging multiproduct crop with a great demand in the country which is cultivated in the tropical and subtropical regions globally and contributes to 70 per cent of the world's sugar (Singh et al., 2011). Besides sugar production, it has also produced byproducts like Bagasses and Molasses in the world (Islam et al., 2001 and Vishwakarma et al., 2013). About 55 diseases of sugarcane caused by fungi, bacteria, virus, phytoplasma and nematode have been reported from India (Rao et al., 2002). Pokkah boeng disease of sugarcane was observed for the first time at Java by Walker and Went in 1896.

Three to seven month old sugarcane is more susceptible to infection than the plants in later stages of growth (Siddique, 2007). The pathogen can survive for 12 months in the plant debris under natural conditions and it can remain viable for more than 10 months under laboratory conditions. It is also reported that survival of pathogen can observed for 12 
months, although incidence is noticed low after nine months. Increasing trend of disease incidence was observed and it was ranged between 1 to 90 per cent in S 224/20 and 5 to 30 per cent was noticed in CoSe 01434 (Vishwakarma et al., 2013). It was also found major constraints in sugarcane production and was becoming predominant disease in China during the recent year (Wang et al., 2016).

\section{Materials and Methods}

To assess the disease status and varietal susceptibility of Pokkah boeng disease, an extensive survey was conducted in sugarcane reserved areas of North Bihar i.e. Pusa, Kalyanpur, Hasanpur, Harinagar, Narkatiaganj, Manjhaulia and Madhopur during crop season of 2017-18. Ten plots in each area were visited and observations were recorded on randomly selected hundred canes from four different locations at each plot to assess the incidence of the disease, which was calculated by using the following formula:

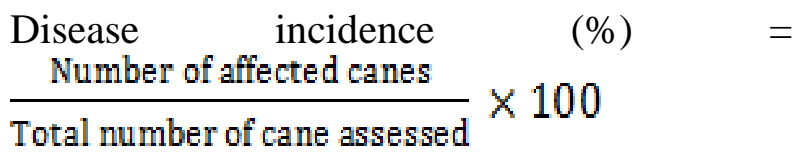

The status of Pokkah boeng disease was differentiated in three categories viz., mild, moderate and severe infection based on symptoms observed as;

Mild - Green plants with pokkah boeng (curling/twisting of spindle leaves, tearing of leaves, whitish/chlorotic streaks on the leaves) at varying intensities.

Moderate - Yellowing of $3^{\text {rd }}$ or $4^{\text {th }}$ leaf followed by complete yellowing of foliage and expression of top rot symptom.

Severe - Yellowing of leaves + discolouration (light coloured) of stalks + wilting symptom in opened stalks.
Twenty two genotypes including one check of different maturity groups were evaluated on the basis of the resistance and susceptible reaction of the varieties in natural condition. Observations for disease development on the individual variety were taken to know their response to pathogen. The presence or absence of disease in field was identified on the basis of symptoms i.e. chlorosis, top rotting and knife cut stage, therefore, disease incidence was calculated as number of infected plants showing above mentioned any single symptom out of the total number of sugarcane plants observed. Disease incidence is the percentage of diseased plants in the sample or population of plants. Estimation of the plant disease incidence was done by using the formula mentioned above.

Twenty two genotypes including one check of different maturity groups were evaluated on the basis of the resistance and susceptible reaction of the varieties in natural condition. Observations for disease development on the individual variety were taken to know their

response to pathogen. The presence or absence of disease in field was identified on the basis of symptoms i.e. chlorosis, top rotting and knife cut stage, therefore, disease incidence was calculated as number of infected plants showing above mentioned any single symptom out of the total number of sugarcane plants observed. Disease incidence is the percentage of diseased plants in the sample or population of plants. Estimation of the plant disease incidence was done by using the formula mentioned above.

\section{Results and Discussion}

\section{Survey of disease}

An extensive survey was conducted with special reference to the Pokkah boeng disease of sugarcane in reserved areas of sugarcane viz., Pusa, Kalyanpur, Hasanpur, Harinagar, 
Narkatiaganj, Majhaulia and Madhopur to observe the status of the disease. The incidence of the disease and its status were recorded and data presented in the table 1 .

It is evident from the data that the disease was prevalent in all the sugarcane growing areas which were surveyed during cropping season of 2017-18. The incidence of the disease varied from 1.1 to 21.2 per cent under different localities and varieties. However, maximum $(21.2 \%)$ incidence was recorded with variety CoSe 95422 which was planted in Breeding experimental trial Sugarcane Research Institute, RPCAU, Pusa followed by the same variety (CoSe95422) and (Co1148) being 20.8 and 19.2 per cent, respectively, which were planted in the Plant pathology trials. The lowest $(1.1 \%)$ incidence of the disease was observed with variety $\mathrm{CoP} 112$ planted in trials of Entomology, Sugarcane Research Institute, RPCAU, Pusa, Samastipur.

The incidence of disease was observed in different localities of reserved areas of sugarcane which was indicated that severity of disease was on variety CoSe 95422 planted in two locations i.e., pathology and breeding trails. The incidence was observed from mild to moderate on remaining varieties which were located under Pusa, Kalyanpur, Hasanpur, Harinagar, Narkatiaganj, Majhaulia, and Madhopur sugarcane reserved areas. Among varieties, only one (CoSe 95422) variety was found under severe form, five varieties $(\mathrm{CoS} 8436, \mathrm{BO} 156$, Co 1148, Co 0238 and Co 0118) were observed under moderate incidence and remaining varieties (BO 139, CoP 9301, BO 91, BO 154, BO 153, CoP 16437, CoP 2061, CoP 112 and BO 141) were recorded with mild incidence.

Karuppaiyan, et al., (2015) also reported Pokkah boeng disease incidence ranged from 6.9 to 25.30 per cent. Duttamajumdar (2004) also observed that incidence of Pokkah boeng disease from trace to moderate level on most of the commercial varieties.

Goswami et al., (2013) reported that not only in India but the disease was present in most of the sugarcane producing areas of the world, causes yield losses in sugarcane varied from 40 to 60 per cent in the susceptible varieties.

\begin{tabular}{|l|l|}
\multicolumn{1}{|c|}{ Incidence percentage } & \multicolumn{1}{c}{ Status } \\
\hline $\mathbf{0 - 1 0}$ & Mild \\
\hline $\mathbf{1 0 - 2 0}$ & Moderate \\
\hline $\mathbf{2 0}$ & Severe \\
\hline
\end{tabular}

\section{Disease reaction}

\begin{tabular}{|c|c|}
\hline Scale (\%) & Rating \\
\hline $0-5$ & Resistant \\
\hline$>5-10$ & Moderately susceptible \\
\hline$>10-20$ & Susceptible \\
\hline$>20$ & Highly susceptible \\
\hline
\end{tabular}


Table.1 Status of disease at different locations

\begin{tabular}{|c|c|c|c|c|}
\hline \multicolumn{2}{|r|}{ Location } & Varieties & $\begin{array}{c}\text { Disease incidence } \\
(\%)\end{array}$ & Disease status \\
\hline A. & PUSA & CoS8436 & 14.1 & Moderate \\
\hline \multirow[t]{11}{*}{1.} & Plant pathology trial & BO139 & 8.6 & Mild \\
\hline & & CoP9301 & 5.0 & Mild \\
\hline & & BO91 & 4.2 & Mild \\
\hline & & BO154 & 6.0 & Mild \\
\hline & & BO153 & 4.2 & Mild \\
\hline & & CoSe95422 & 20.8 & Severe \\
\hline & & BO156 & 12.0 & Moderate \\
\hline & & Co1148 & 19.2 & Moderate \\
\hline & & CoP16437 & 3.4 & Mild \\
\hline & & CoP2061 & 3.0 & Mild \\
\hline & & CoP112 & 2.1 & Mild \\
\hline \multirow[t]{4}{*}{2.} & Entomology trial & BO 154 & 8.2 & Mild \\
\hline & & CoP 2061 & 4.2 & Mild \\
\hline & & BO153 & 3.2 & Mild \\
\hline & & CoP112 & 1.1 & Mild \\
\hline \multirow[t]{7}{*}{3.} & Breeding trial & BO154 & 9.0 & Mild \\
\hline & & BO153 & 3.4 & Mild \\
\hline & & CoP9301 & 7.2 & Mild \\
\hline & & BO91 & 6.2 & Mild \\
\hline & & СoP2061 & 6.1 & Mild \\
\hline & & CoP112 & 3.0 & Mild \\
\hline & & CoSe 95422 & 21.2 & Severe \\
\hline \multirow[t]{7}{*}{4.} & Agronomy trial & BO154 & 6.2 & Mild \\
\hline & & CoP2061 & 6.4 & Mild \\
\hline & & BO153 & 2.6 & Mild \\
\hline & & CoP112 & 1.8 & Mild \\
\hline & & CoP9301 & 6.2 & Mild \\
\hline & & CoP16437 & 4.1 & Mild \\
\hline & & BO141 & 8.2 & Mild \\
\hline \multirow[t]{3}{*}{5.} & Soil science trial & BO154 & 5.2 & Mild \\
\hline & & CoP2061 & 2.0 & Mild \\
\hline & & CoP112 & 1.4 & Mild \\
\hline & KALYANPUR & BO153 & 4.4 & Mild \\
\hline & & BO154 & 6.2 & Mild \\
\hline & & CoP2061 & 8.1 & Mild \\
\hline & & CoP112 & 4.6 & Mild \\
\hline
\end{tabular}


Continue........

\begin{tabular}{|c|c|c|c|c|}
\hline & \multirow[t]{6}{*}{ HASANPUR } & CoP2061 & 4.3 & Mild \\
\hline & & CoP112 & 1.4 & Mild \\
\hline & & Co0238 & 12.2 & Moderate \\
\hline & & Co0118 & 11.3 & Moderate \\
\hline & & BO154 & 6.2 & Mild \\
\hline & & CoP9301 & 3.2 & Mild \\
\hline \multirow[t]{8}{*}{ D. } & \multirow[t]{8}{*}{ HARINAGAR } & CoP9301 & 4.1 & Mild \\
\hline & & BO154 & 8.2 & Mild \\
\hline & & BO153 & 4.6 & Mild \\
\hline & & CoP113 & 1.6 & Mild \\
\hline & & CoP2061 & 4.6 & Mild \\
\hline & & $\mathrm{Co} 0238$ & 10.2 & Moderate \\
\hline & & Co0118 & 11.8 & Moderate \\
\hline & & BO91 & 4.4 & Mild \\
\hline \multirow[t]{8}{*}{ E. } & \multirow[t]{8}{*}{ NARKATIAGANJ } & Co 0238 & 16.1 & Moderate \\
\hline & & Co0118 & 12.6 & Moderate \\
\hline & & BO91 & 4.2 & Mild \\
\hline & & CoP2061 & 6.2 & Mild \\
\hline & & CoP112 & 3.6 & Mild \\
\hline & & CoP9301 & 4.1 & Mild \\
\hline & & BO154 & 7.2 & Mild \\
\hline & & BO153 & 6.4 & Mild \\
\hline \multirow[t]{6}{*}{ F. } & \multirow[t]{6}{*}{ MAJHAULIA } & CoP2061 & 4.6 & Mild \\
\hline & & CoP112 & 1.6 & Mild \\
\hline & & BO91 & 6.2 & Mild \\
\hline & & $\mathrm{Co} 0238$ & 18.2 & Moderate \\
\hline & & Co0118 & 12.4 & Moderate \\
\hline & & BO154 & 6.2 & Mild \\
\hline \multirow{5}{*}{\multicolumn{2}{|c|}{ G.. MADHOPUR }} & CoP2061 & 3.6 & Mild \\
\hline & & CoP112 & 1.8 & Mild \\
\hline & & BO154 & 6.2 & Mild \\
\hline & & BO153 & 2.4 & Mild \\
\hline & & CoP9301 & 4.2 & Mild \\
\hline
\end{tabular}


Table.2 Evaluation of varieties against Pokkah boeng disease

\begin{tabular}{|c|c|c|c|}
\hline S. No & Varieties & Incidence Percentage & Disease Reaction \\
\hline 1 & BO139 & 3.2 & $\mathrm{R}$ \\
\hline 2 & CoP9301 & 2.0 & $\mathrm{R}$ \\
\hline 3 & BO91 & 3.6 & $\mathrm{R}$ \\
\hline 4 & CoS8436 & 18.2 & $\mathrm{~S}$ \\
\hline 5 & BO153 & 1.6 & $\mathrm{R}$ \\
\hline 6 & BO154 & 3.4 & $\mathrm{R}$ \\
\hline 7 & CoP 16437 & 2.2 & $\mathrm{R}$ \\
\hline 8 & BO156 & 6.2 & MS \\
\hline 9 & Co1148 & 14.6 & $\mathrm{~S}$ \\
\hline 10 & СoР2061 & 4.2 & $\mathrm{R}$ \\
\hline 11 & CoP112 & 2.1 & $\mathrm{R}$ \\
\hline 12 & CoP16440 & 3.8 & $\mathrm{R}$ \\
\hline 13 & BO155 & 8.4 & MS \\
\hline 14 & CoP11438 & 6.2 & MS \\
\hline 15 & BO130 & 18.6 & $S$ \\
\hline 16 & CoSe 92423 & 22.2 & HS \\
\hline 17 & CoSe13451 & 12.2 & $\mathrm{~S}$ \\
\hline 18 & CoP13436 & 9.2 & MS \\
\hline 19 & CoP13437 & 2.4 & $\mathrm{R}$ \\
\hline 20 & CoP13438 & 4.6 & $\mathrm{R}$ \\
\hline 21 & CoSe 13452 & 3.6 & $\mathrm{R}$ \\
\hline 22 & CoSe95422 (Check) & 26.6 & HS \\
\hline
\end{tabular}

R - Resistance, MS - Moderately Susceptible, S - Susceptible, HS - Highly Susceptible

\section{Evaluation of varieties}

Twenty two varieties (Table 2) namely, BO139, CoP9301, BO91, CoS8436, BO153, BO154, CoP16437, BO156, Co1148, CoP2061, CoP112, CoP16440, BO155, CoP11438, BO130, CoSe92423,CoSe 13451, CoP13436, CoP13437, CoP13438, CoSe13452 including one check (CoSe95422) were evaluated under natural condition. Out of twenty two varieties, twelve varieties viz., BO139, CoP9301, BO91, BO153, BO154, CoP16437, CoP2061, CoP112, CoP16440, CoP13437, CoP13438 and CoSe13452 were found resistant, four varieties viz., BO156, BO155, CoP11438 and CoP13436 were observed moderately susceptible and four varieties viz., CoS8436, Co1148, BO130 and CoSe13451 were found susceptible. Only two varieties namely, CoSe92423 and CoSe95422 were observed highly susceptible to Pokkah boeng disease. The varieties found resistant reaction against Pokkah boeng disease may be used as a source of resistance for further breeding programme to develop resistant varieties. Wang et al., (2017) and Vishwakarma et al., (2013) also evaluated several varieties were resistant and moderately resistant reaction against the disease.

An extensive survey was carried out to know the disease status in different cane growing areas of Bihar and it was observed that the 
prevalence of pathogen in Bihar with variable magnitude of incidence ranging from 1.1 to 21.2 per cent. The maximum $(21.2 \%)$ incidence was recorded in variety CoSe95422 and minimum $(1.1 \%)$ incidence was observed in variety CoP112.

Twenty two varieties were evaluated of which twelve varieties were found resistant, four varieties were moderately susceptible and four varieties were susceptible while, two varieties, namely CoSe92423 and CoSe95422 were observed highly susceptible to Pokkah boeng disease.

\section{References}

Duttamajumder, S. K (2004). Bacterial diseases of sugarcane in India: a bird's eye view. In: Sugarcane pathology: bacterial and nematodes diseases, Rao, G.P., Saumtally, A. S., Rott, P. (eds.). Science Publishers. Pp. 15-50.

Goswami, D., Handique, P. J., Deka, S. (2013). Rhamnolipid bio surfactant against Fusarium sacchari the causal organism of Pokkah boeng disease of sugarcane. Journal of Basic Microbiology. Pp. 1-10.

Islam, M. S., Miah, S. A. M., Begum, K. M., Alam, R. M. and Arefin S. M. (2001). Growth, Yield and Juice Quality of Some Selected Sugarcane Clones Under, Water Logging Stress Condition. World Journal of Agricultural Sciences, 7: 504-509.

Karuppaiyan, R., Bakshi, R., Ramdiya S., Masawwar A. and Meena, M. R. (2015) The incidence of Pokkah boeng in indigenous and exotic sugarcane
(Saccharum officinarum) clones. Indian Journal of Agricultural Science, 85(4): 596-601.

Rao, G. P., Vishwanathan, R. and Singh, S. B. (2002).Current situation of sugarcane diseases in India. In: Sugarcane crop management, (Ed.) S. B. Singh, Rao, G. P. and Easwaramoorthy, S., 734. Houstan: SCI Tech Publishing LLC.

Siddique, S. (2007). Pathogenicity and aethiology of Fusarium species associated with pokkah boeng disease on sugarcane. Thesis, University of Malaysia, Malaysia.

Singh, R. K., Khan, M. S., Singh, R. Pandey, D. K., Kumar, S. and Lal, S. (2011). Analysis of genetic differentiation and phylogenetic relationships among sugarcane genotypes differing in response to red rot. Sugar Tech. 13(2): 137-144.

Vishwakarma, S. K., Kumar, P., Nigam, A., Singh, A. and Kumar, A. (2013). Pokkah Boeng: An Emerging Disease of Sugarcane. Journal of Plant Pathology and Microbiology. Vol. 4:3

Wang, Z. P., Sun, H. J., Guo, Q., Xu, S. Q., Wang, J. H. and Lin, S. H. (2017). Artificial inoculation method of pokkah boeng disease of sugarcane and screening of resistant germplasm resources in subtropical china. Sugar Tech. 19(3): 283-292.

Wang, Z.P., Duan, W. X., Li, Y.J., Liang, Q., Zhou, Z. G., Zhang, M.Q. and Lin, S. H. (2016). Establishment of resistance evaluation system in the field for sugarcane Pokkah boeng. Journal of South China Agricultural University. 37(3): 67-72.

\section{How to cite this article:}

Abhay Ranjan, Md. Minnatullah, Hari Chand, Shiv Pujan Singh and Saurabh Dubey. 2018. Evaluation of Sugarcane Varieties against Pokkah boeng Disease and its Natural Occurrence. Int.J.Curr.Microbiol.App.Sci. 7(10): 44-50. doi: https://doi.org/10.20546/ijcmas.2018.710.006 